\title{
TALES OF UUDE OF HULJA
}

\section{Mall Hiiemäe}

No historian or chronicler could have managed to reproduce the life of ancient Estonians as completely, as vividly and as accurately as peoples' own recollections and comments have done.

Dr. J. Hurt, Olevik 1894, no. 3

Jakob Hurt, the initiator and organiser of the large-scale gathering of Estonian folklore, called upon the people to treasure its oral heritage arguing that folklore is the purest reflection of a nation's life. The current article will indicate that the abundance of information available on Uude of Hulja, a character in the folktales that will be discussed below, originates in the oral narrative heritage. The Estonian Folklore Archives at the Estonian Literature Museum have received accounts concerning him, although inconsistently, from 1899 to the present day, i.e. throughout the entire century. At the end of the 19th century and the beginning of the 20th century, gatherers of folklore did not have a high regard for stories about persons of local importance, and in fact they were not considered to be part of folklore. Even so, the archives contain several recordings from this period (E 38318/9; 38463; 4341/2). Later, the collection of local heritage initiated by the Estonian Folklore Archives and carried out in schools during 1938-1939 brought Uude of Hulja to the centre of folklorists' attention as a legendary person (volumes ERA II $131 ; 132 ; 216 ; 222 ; 279$ ). The bulk of the material was collected during the second half of the 20 th century, i.e. since the 1965 folkloric field work performed in the region where Uude of Hulja had been active, and was inspired by the author's special interest in the origin and elaboration of local tales (RKM II 83; $251 ; 254 ; 261 ; 262 ; 275 ; 283 ; 293 ; 297 ; 309 ; 367 ; 371 ; 415 ; 442)$.

According to the parish registers, Kustav Udeberg, son of Rein, was born in Hulja village, Undla parish, Kadrina district on June 1,1862 . The boy, prematurely bereft of his parents, was soon cast among people dependent on the communal welfare, whose social status was generally determined by a deficiency (either mental or 
physical). His family name gave him the nickname Uude, and he came to be called Uude of $(\mathrm{H})$ ulja after the village where he was born.

In folktales Kustav Udeberg was known neither as a man of muscle like Georg Lurich (1876-1920, nickname Luuri), the famous Estonian wrestler who came from the neighbouring parish, nor was he a storyteller like Jakob Puu (1879-1964, also known as PuuJaagup), who had lived in the same region and had become famous for fabricating tall tales. He was neither a religious zealot like Juhan Leinberg (1812-1885) aka Prophet Maltsvet (cf. Masing 1993: 115$118 \mathrm{ff}$ ), who was known in the northern part of Estonia, nor was he anything like Jaan Valge (known as Kordo), a visionary witchprophet in southeastern Estonia, the contemporary of prophet Maltsvet, whose popularity in the oral narrative has, like Uude, lasted for the whole century (cf. Salve 1999: 247-248). Uude does not fit into any of the ten categories in the "typology of madmen" by Orrin E. Klapp (1980), nor can he be forced under any of the seven categories in the classification of village fools established by Hannes Sihvo (1990: 30-38).

How then should we characterise Uude of Hulja of the folktales? Was he a half-wit or highly intelligent, an innocent victim or an artful schemer, a person easily adapting to the social relations of the village community or an outcast, a beggar travelling from village to village and from house to house, or his own man, was he a solitary dissident or an advocate of community attitudes? According to the village people he was all of these things. He was certainly eccentric and different from ordinary villagers, but at the same time he was also the mirror of the village community, and could be characterised by an Estonian proverb: "As the village does to me, so I do to the village".

People remember Uude of Hulja as having been quite tall, at least taller than average, possessing high cheek-bones, a wide nose like that of Santa Claus, a reddish full beard, slightly curly hair (in Nurkse village people told he had "long hair waving in wisps on his back"). According to a report from Karunga village he had "strong shanks like elephant's legs" and Väljataguse village provided the comparison: "Feet as large as spades. When he walked barefoot, his foot became flat." Uude spent all his life walking from family to family, village to village, parish to parish, district to district. He 


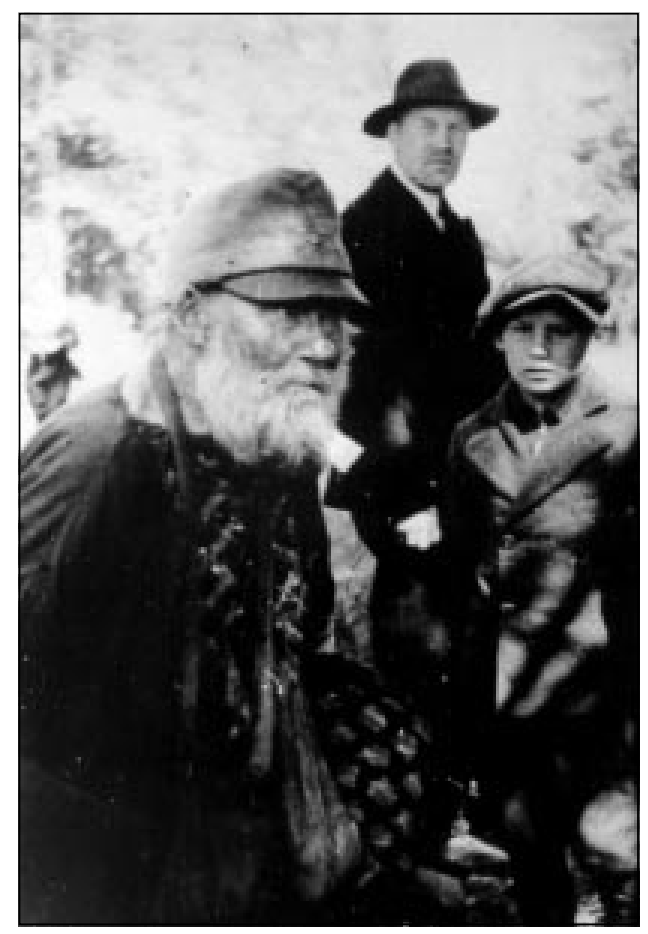

Uude of Hulja on a cemetery holiday in Haljala when he was about 70 years old. The photo was taken without his knowledge as Uude would not have allowed taking a photo of himself. ERA 10231.

was most often seen in Haljala, Rakvere and Viru-Jaagupi parishes, sometimes also in Järva-Jaani parish in the Lääne Virumaa region. Thus Uude did not stay within the borders of his home parish as stipulated by the contemporary regulations for supporting the parish poor, but his travels covered an area of approximately $40 \times 50 \mathrm{~km}^{2}$, extending from the villages between the fields and forests of Virumaa to the coastal villages along the shore of the Gulf of Finland. This territory, including the more distant places where the traveller was occasionally spotted, might be estimated as being approximately $60 \times 70 \mathrm{~km}^{2}$. In village people's recollections Uude has said the following of his wanderings: "Virumaa is the distance between one's feet" (Kadrina v.); "I have one foot in Kadrina and the other in Ambla parish" (Põdruse v.); "Haljala parish is like walking the distance around a tethering stake" (Avido 
v.). Uude considered Kadrina parish to be extremely small: "You put one foot next to the river behind the Kadarpiku farm and the other foot on Kolu manor" (Mädapea v.). The church would have been right at the kneecap (Nõmme v.). Uude has also said: "The country of Estonia is as small as the distance between two steps" (Haljala v.). He is known to have given the same response to the question: "Have you been to Tartu?" (Läsna v.). The figure of speech about the distance between the feet (or between the footsteps) occurs in a combination of different place names (several other villages and even towns), some of them are actually places where the traveller had never really been to. He could name all of the coastal villages (on the eastern coast of Estonia) between Tallinn and Narva, and used to say: "If I were to walk from Narva to Tallinn, the church of Haljala would be just between my feet" (Kõldu v., the approximate distance $200 \mathrm{~km}$ ).

In Pihuvere village, people said that Uude's mother had wished that her son would become a very famous man. An account from Rakvere relates that his mother had once said: "When I have a baby, it will be like a wild strawberry." Folk religion forbids such direct bragging, and the boaster will be punished for it. A folktale from East Estonia, narrated by a woman born in 1947, could serve as an example here:

There was a man in Kilbavere village who always laughed at other people's children and said they were ugly. He said: "My child will be a real doll." And he got a child who was like a doll: namely, it grew to the height of 1 metre and no more. RKM II 369,115 (2) < Maarja-Magdaleena parish (1983)

It is not known whether the cotter's wife from Hulja village really had such high hopes for her baby, or if this was subsequently recounted by the villagers. The folklore archives even contain an account purporting someone to have told Uude's mother: "Your son will be the laughingstock of the whole world" (Levala v.). Uude's fate was indeed to become the laughingstock of the world, but on the other hand, in the places where he went there was no man, be he landlord, priest or merchant, more famous than he.

Accounts of Uude's childhood do not vary much. Certainly, at this time it was not known that the boy would become famous, and 
thus the things he did did not receive the attention later life. According to a story recorded in Karunga village, the boy was said to have once poured petrol on a cat and then set it on fire, saying: "Look at that firebomb!" The cat ran to the hayloft, but the firebomb did not cause the feared result. Another account says that the boy had lit a stack of sticks while waiting for his mother, with the calculation that then his mother would see the fire and return home (Kõrgemäe v.). Once his mother went to sell butter, and when the firkin was opened the onlookers saw a layer of mashed potatoes set on wooden splinters and a thin layer of butter spread over that: Uude had "tasted" the rest of it (Katku v.). The butter-selling event has been recorded from several villages. When his mother sold the cow and had stored a bucketful of milk to last for a longer time, Uude had poured all of it in a pot and said later: "What a fine soup that was!" (Karunga v.). The popular story about teaching a lamb to read must come from Uude's childhood as well. Uude had tried to teach a lamb to say "ee", but the latter kept bleating "baa", so Uude had punished the lamb by pushing it onto burning ashes. A version of this story says that he had burnt the lamb's feet with a firebrand. The first recording of this account comes from 1902 when Uude was an adult man of 40 years. This account also provides an explanation for the unusual event: just before that Uude's mother had taught him the alphabet.

Several stories relate to the behaviour of the boy after his mother had died. The funeral story is apparently the most poetic of all: The mother died. The boy inherited half a measure of barley. He had shaken down the grain, saying: "Flycatchers, tick, tick, come and feast at my mother's funeral!" (Salla v.). According to one account Uude had inherited a sack of grain from his mother, according to another a tub and a yarn reel. The boy is said to have made a hole in the bottom of the tub, stuck the reel inside the hole and placed the tub on his head (Tirbiku v.). People from Pajusti village related how the sauna had been swarming with bedbugs; Uude had set the sauna on fire and danced around it: "Let the bedbugs burn." The latter story is known in several parts of Estonia and has been attributed to different persons, and a number of the recorded accounts attribute it to Uude as well. When exactly Uude was deprived of his mother is debatable. For example, in Jõepera village people recounted that "after the third grade, his mother 
died", but in Läsna village Uude's words were recalled: "He himself has said that when he turned 20, his mother forced him to work and make hay. But he had said to his mother: "You haven't got a room for me that would keep warm without heating, or give me food I would not have to work for. I will go out into the world."

How should we look upon Uude's boyhood tricks if we assume that they might have happened in reality? According to the accounts we cannot really ascribe him mental disabilities. His actions rather suggest the lack of critical sense common to a tramp who has grown up alone. Many village people have argued over why Uude's behaviour was so strikingly different during his whole life, and whether he was a fool or not. Apparently the hunger he so often felt in his childhood and also the understanding that hard work does not always put food on the table were what led him to choose the lifestyle he did.

As Uude's father had died earlier, his mother had to work hard to make ends meet. The boy used to run to the village, where people gave him food. And when his mother had gone looking for him, she found him asleep and did not want to wake him. So the boy got used to staying with other families and realised that one can get food without having to work for it. The following is the recollection of an old man from Jõepera village who had heard it from his father (the latter had apparently attended the village school with Uude). When Uude was asked: "Why haven't you got a home?" he answered: "If I had, it wouldn't be anything better than what I have now, my home is everywhere" (Väljataguse v.). And to the question: "Where are your parents?" he responded: "It is always like that: those who work hard will depart before their time." Uude's answers to similar questions often suggest shirking, which is rather uncommon in village communities: "Bread doesn't taste better if you had to work for it" (Kôldu v.); "I wonder if this bread you have worked so hard for tastes better" (Ohepalu v., Pihuvere v.); "I have reached this age in my life, but haven't yet noticed that the bread one earns through work is better than that one hasn't had to work for" (Põdruse v.); "I have no intention to start working for a landlord on the land that is God's" (Avido v.); "Seven ovens bake me bread every day, why should I work" (Ojaveski v.); "I don't think the bread you work for is better than the bread I get on my travels" (Lepna v.); "Work is the pastime of fools" (Rakvere town). Such were 
Uude's responses when he was encouraged to work, or asked, for instance, to chop wood: "Chopping wood doesn't make the bread taste better. I'll get food anyway."

Upon encountering Uude, the subject of shirking was often taken up by the village people, and Uude's quite figurative responses remained more or less the same. Here we face an interesting phenomenon in the formation of oral narrative: namely, a saying, which in most cases becomes the critical point in the narrative, will become established in the tradition by the character's own recurrent usage of his personal formula. Thus we are concerned with a special incidence of the Law of Stability formulated by Walter Anderson, one of the leading figures of the comparative-historical school (See Hiiemäe \& Krikmann 1992: 127 ff.), although chances for its further observation in the "field" are rather limited for several reasons.

All of Uude's comments on his homelessness, clothing, employment and choice of routes in the text below, which were recorded already at the beginning of the 20th century, were used publicly decades after Uude's death. And as Uude's ingenuity has been witnessed by most of those who have met him, we have reason to believe that all of his comments in the text below have been recorded without major changes.

Uude the Beggar.

Once I met beggar Uude near Rakvere. He was leaning on crutches and had tied huge horns on his head. He asked if I had tobacco. (Some people think he's a real fool, others think he's a buffoon.) I asked him: "What's your name? In which parish are you registered?"

"I'm in the same 'revision' with birds, I have no home. And I suffer from not having good clothes like the skin that foxes and hares have," he answered.

"You seem to be a sturdy man, why don't you work?" I asked him. "So that you could eat bread that you have earned?"

"Does the bread you have earned taste sweeter than the bread you are given free?" the beggar replied.

Another time I saw him standing in a village street, leaning on a stick and thinking. "What are you thinking?" I asked him. 
He replied: "Hens never brood all of the eggs, some go bad. I never visit all the farms either, some become like rotten eggs." $\mathrm{E}$ $43041 / 2$ < Haljala parish, Kloodi village - J. Laarmann (1902)

Uude had hated work since his childhood. The question: "Have you ever done a day's work in your life?" received the answer: "When mother was alive, I had to work." There was a saying about his idleness: "You are as lazy as that Uude." And when he was asked about his quivering hands, he replied: "They must tremble from fear of work." In Avido village people used to say that once, harvesting potatoes with his mother on the landlord's field, Uude had picked his nose till it was bleeding and thus got away from the work he loathed. The overseer kept driving the boy back to work, but he climbed on the one and then the other side of the sauna roof. The overseer got tired of playing tag and said: "You will come to nothing as a worker" (Väljataguse v.). The boy had told his mother: "Don't you worry, the world will feed me" (Kõrveküla v.).

Actually, Uude "knew how to work". In several farms people remembered that he used to come and help out, he was good at scything, he had unearthed a pile of potatoes, and turned the chuffcutter. But if he was offered food before work, he tried to sneak out of the house without setting to work. In Kloodi village he was once given a sickle with which to reap rye, and Uude had cut buttons off his pants and when the landlady had sent him to the house to sew the buttons on, Uude had secretly snuck out and gone his way.

As to the formation of Uude's social status, it would be important to learn whether apart from his short-term jobs he did hold any permanent occupation, at least at the beginning of his adult life, if not later. Information about this is far too insufficient. It is also possible that the role attributed to Uude excluded any further distribution of similar information. In any event, the archives contain only one and rather early account (Uude was 37 years of age) including a list of Uude's occupational endeavours. In retrospective, it is difficult to tell whether the list of occupations was the product of the shirker's own imagination or was a deliberate exaggeration by the narrator, or whether Uude was indeed engaged in some steady work. Judging by the fact that the informants born in 1885 and later recalled having met Uude when he was still a boy, we can 
conclude that by the turn of the century Uude was, in his $40 \mathrm{~s}$, already known as a traveller.

Kustas of Hulja had tried all kinds of jobs, but was still living in poverty! He had been a landlord, a farm-boy, a cobbler, a tailor, a blacksmith, a carpenter, a painter, a weaver, an overseer, but was still in trouble. Finally he started begging. Other people had said: "How dare you to ask alms, you should be working." - "Well, does the bread you work for taste sweeter than the one I get by begging. See, this is how I'll become rich.” E 38318/9 (15) $<$ Ambla - J.Neublau (1899)

People say that when the boy's mother had sent him to school, he had sat on a hilltop until the classes were over (Aruküla v.), skipped school (Kloodi v.) and been a wayward pupil (Põdruse v.). A man who had attended school with Uude has said that Uude knew how to read and write, and that the schoolmaster had graded his knowledge in religious instruction to be excellent. This information, based on his father's stories, was recalled by a man from Jõepere village. The accounts about Uude's attending confirmation classes also appear contradictory. Uude was said to have been illiterate: he had attended confirmation classes for three years, but had "failed" (Avido v.). One of his fellow confirmees has also admitted that Uude could not read (Pihuvere v.). According to another fellow confirmee, Uude had been "sound and sane". It seems as if Uude, for some reason, deliberately behaved as a fool. In any case, the 8th volume of the personal register of Kadrina congregation includes a record on page 52, stating that Kustav Udeberg received confirmation on April 6 th, 1880. At that time he was 17.

Several narratives describe Uude's mode of behaviour and attitudes, illustrated by some of his sayings. In the tales of Uude this method of narrative formation occurs most often. The author of this article has described the application of this method during the observation of the process in the tales of Kodavere, and summarised as follows: "The saying naturally occurs most often in the stories which focus on a person with all his traits of character, skills and peculiarities. The plot of such stories is often inadequate, the course of events almost non-existent, and the stories present just a momentary situation. In stories which focus on a certain event or where the course of events is more elaborate, a saying often functions as a 
secondary and rather illustrative part” (Hiiemäe 1978: 71). Such stories presumably circulated particularly during the time when the eccentric parish pauper was no longer among the living, and were passed on as recollections to the younger generation who had not met him in person. This has lasted up to the present day. Uude never greeted anyone, nor did he express gratitude for anything. He never asked for anything but a light for his cigarette, often not even that. Once, Uude had spent half a day in Väljataguse village, all of the others had smoked the whole time but Uude waited for the others to offer him a light for his cigarette. He also chose where he went, never visiting all the households, although the parish had supposedly granted him permission to do so. He never spent much time in one place, staying for a mealtime, or overnight, and during a snowstorm even for a couple of days. He never again visited families where he had not been received very warmly (if he was not given food right away, the children teased him, or the adults laughed at him or made fun of him). People in Kõrveküla recalled that a ploughman had seen Uude in Läsna village, a block of wood tied in front of his eyes: "I don't wish to see you or your Läsna village." Uude had divided the village community into his "own people" and the "strangers", emphasising the difference in his straightforward manner. People remembered him as having said: "If they don't care about me, I don't care about them" (Avido v.); "I look for honest people" (Potsu v.). When someone whom Uude did not happen to like had invited Uude to stay in his home he continued on his way, saying: "Nobody tells me where to go" (Saksi v.); "I'll do as I please" (Katku v.). When he was asked: "Where are you going now?" he used to answer: "I'll go where I like" (Sootaguse v.). Choosing his way as he did, he could also choose his direction: "I don't have to go windward if I can go leeward" (Pihuvere v.); "I'm nothing like you who struggle up the wind, I'll go leeward" (Avido v.). When people suggested Uude should buy a bicycle, he had answered: "I'm in no hurry, why should I get myself a bike?" (Avido v.). Still, people remember him having walked on crunches or stilts, and once he was chased with a horse to tell him not to frighten people on the road, but Uude had escaped (Väljataguse v.).

Uude had commented on the necessity of greeting people as follows: "What does 'hello' mean. Saying hello is like picking a fight" (Nõmme v.); "I know the people whether I greet them or not" (Põdruse v.); "Will you be a better man if I greet you" (Järni v.). 


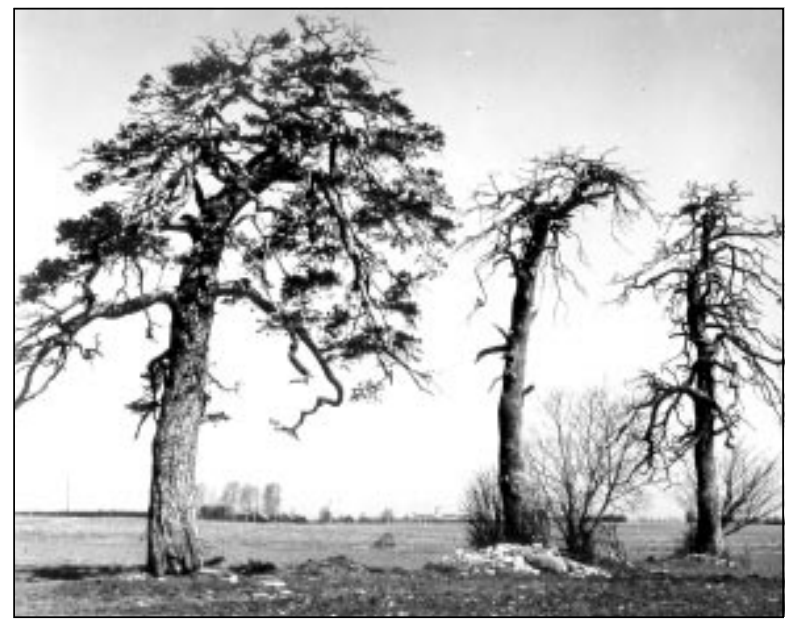

Landscape near Uude's birthplace, Hulja village. Photo by H. Joonuks. Photo collection of the Estonian Folklore Archives.

Several families remembered the following reason for not saying hello: "If you knock on the gate and say hello, the dogs will fly at you." So, Uude's whim turned out to be his wisdom. The same applied to saying goodbye: "I'll be back, I won't say goodbye" (Haljala parish).

In summer, Uude was often spotted on the beaches, where holidaymakers would give him money, which he spent right away. In towns he was harassed by the police, so he went there only in case of emergency: "It is a town of farm hands, I don't go there," he said of Rakvere town. Still, he was seen at the fairs and at a "cemetery Sunday' in Järvamaa. Having met a parish pauper at some of the events, he had said: "This place is not big enough for two fools," and left (Rägavere v.).

It was general knowledge why Uude never carried matches with him; he had only two pipes, one of which had a huge bowl where Uude kept his tobacco. The pipe bowl held a whole packet of tobacco. As for matches, the smoker himself said that if he had any, it would be his fault if the house caught fire. According to the people of Aruküla, Uude had said that he could take his own matches if the houses had iron beams and tin roofs or were made of stone. 
This fear of accusation might have resulted from his having played with matches in childhood. According to a report from Nõmme village, as a young man Uude had been responsible for setting a barn on fire, and from then on gave up matches. The explanation from Lasila village said that he had been in a hayloft when the house had caught fire, and had to be hospitalised for the burns. Some had said that Uude had been beaten for being responsible for the fire.

Several reports talk of Uude's negative attitude towards money. He had, for example, refused an offer of money by replying: "Money breeds thieves"; "The good thing about money is that it makes people generous. You won't give me [any goods] without money, but when you receive money, you will" (Põdruse v.). Examining the tales concerning Uude in greater depth, one notices that he used sayings like "People don't give me any real money" in shops and other places where people could see him, to leave the impression that he did not value money or fortune. The reason for this was probably so that he would not be accused of theft, or that noone would come and take his money. As an outlaw he had taken other precautions as well. If somebody proposed walking with him, he usually said: "I don't want to walk with anybody. If you died, it would be my fault, I would be accused of your death" (Põdruse v.). In critical situations, he often had to correct people's opinion of him as any asocial person. And when the situation had found its conclusion and happened to attract attention, it provided material for a new tale for the Uude cycle. Consider the following example:

\section{How Uude Carried Potatoes.}

In Ulja village in Kadrina parish there lives a nearly 80-yearold man called Ulja Uude. People tell strange stories about him. I know him personally and have talked to him too. He can imitate a nightingale's song in a very natural manner. He doesn't like working, saying that "The bread I have worked for doesn't taste sweeter!" He goes from family to family and gets his food in this way.

I'll tell a few stories about him:

I stayed with a widow in Sootaguse. (He himself recounted this.) The woman wanted me to go and steal potatoes for her and showed me the neighbour's potato patch. So I carried 18 pounds 
of potatoes and was paid 3 roubles by the widow. Then I left the place, but went back later. The woman started to scold me: "You bugger, you brought me potatoes from my own pit!" I answered: "I couldn't steal, so I took them from your pit, so you could see how it feels when someone steals from you." ERA II 279, 325/6 (31) < Haljala parish, Aruküla village - J. A. Reepärg (1940)

Uude's visits brought some change to the otherwise routine village life, and also brought news from other places. "Uude came only once a year [and we waited] for him to come. He travelled around and brought news" (Haljala p.). Uude never really wanted to stay with the families. This becomes obvious from his choice of resting places. "He refused to come into the chamber, and instead wanted to sleep on the stove wall in the threshing barn," people from Väljataga village recalled. When he stayed in some place for longer, he lived in the threshing barn, the antechamber of the mill, on the stove wall of the distillery or on the pallet in the carpenter's work room at the local estate. He stayed with the estate's herder for the whole week. Perhaps Uude did not wish to abuse the hospitality of kind people. The people of Väljataguse village recalled: "When our father was alive, he stayed with us, but when our father died, he merely looked in the door, saying: "You have no breadwinner, why should I come and stay with you?"' Perhaps he never really understood why he was not regarded as an equal. Although he never told anyone where he intended to go, people still knew that "in sum-

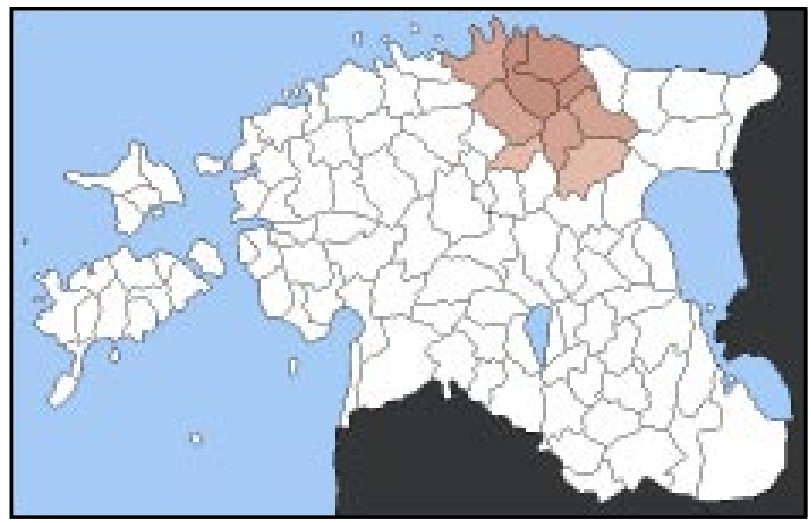

Areas where Uude was known as traveller. 
mertime Uude roamed in the woods and slept wherever he could, in the fields or in the woods" (Rakvere town).

It was clearly not easy for him to beg for food. Even when he was asked, he usually answered: "Why do you ask, give me some if you have some." He also had difficulty expressing gratitude: "Is it any better if I say 'thank you'?" (Kaarli v.); "I didn't ask, so I won't say 'thanks' either" (Ojaveski v.). We might assume that asking for something, or expressing gratitude, but also saying hello and goodbye in Uude's mind somehow emphasised his status as an outcast and thus differentiated him from the villagers. Uude wished to be treated with respect: "Do you serve my food on the stairs, like dog food?" (Salla v.). Once, someone at the blacksmith's in Kõrveküla village said: "Give Uude a piece of bread, he's staring like a dog." Then Uude had started to growl like a dog and sank down on all fours. He was obviously certain that it was the people's wish to feed him. In a way he was right, as feeding the parish poor was very common at that time, and households usually had plenty of food. Uude, however, appeared to be very particular and even fastidious about his food. This is mentioned and argued over in a number of accounts, recalling Uude's words: “Don't give me milk, it is taken from a raw cow's udder. Give me coffee instead" (Põdruse v.); "That is the product of bull's work" (Ohepalu v.); "I don't want small herrings; give me semolina porridge and fruit jelly" (Lasila v.); "Barley broth and small herrings: that is hospital food" (Salla v.); "I don't want cabbage soup. Baby cake [i.e. that taken to a woman in childbed] would be better" (Rägavere v.); "I don't want mashed potatoes" (Karunga v.). In Mägiküla village Uude had argued: "How is that expensive: potato soup, cabbage soup and mashed potatoes with thick lumps in it? This isn't expensive. But cakes and white bread made of sifted flour with raisins in it: well, that is good, but also expensive." While eating Uude always dropped the thicker pieces under the table (Kõnnu v.). He did not like barley cake: "You press the porridge flat on a pan, and do you call that cake?" (Pihuvere v.). He was fond of sweets, which he often bought when he could afford them, but had rejected an offered sandwich: "I'm tired of sandwiches, take it back" (Kõrveküla v.). In Pihuvere village he was also offered a veal sandwich: Uude had eaten the meat and given the bread back, saying it was stale; also, in Essu village he had eaten all the eggs and meat, leaving the small herrings and bread to the others: "Mine isn't food for hay-makers, it is the hay- 
makers who should eat small herrings and bread" (Pajusti v.). Uude has said: "I don't store up food, I get food wherever I go" (Aruküla v.), and he did not carry a food bag with him. The people in Polli village have argued that he was indeed fed everywhere he went, sometimes up to ten times a day. Once Uude had come to a farm at the busiest threshing time and no one had time to serve him food, so he had grumbled: "The world will take care of all that is outside. Why else have I come here? I'm heaven's messenger" (Rakvere town).

The tales suggest that not all days were lucky for Uude. An account from Porkuni village said that Uude had eaten more than 3 litres of sour milk and three pounds of bread all at once, in Põdruse village he had eaten a whole herring at once, in Rakvere his ration had been over one and a half litres of sour flummery and one and a half litres of milk. These individual examples do not, however, suggest he was one of the gluttons known from Estonian folk tales, but simply that he did not eat regularly. Once he ate excessively, and at other times he starved. At holidays, for example: "Now I could eat till I exploded, while sometimes I get nothing" (Aruküla v.). And he could eat to the point of diarrhoea (Põdruse v.). Uude was scarcely ever served food that was considered better in those days. If asked "Have you had coffee?" he had answered: "I had it last year, and can still taste it" (Udriku v.), and in another village he had admitted: "No-one has ever baked a cake for me, it hasn't happened" (Avido v.). In his older years, Uude is known to have carried food in his haversack. Several accounts tell of his cunning, how he let the cattle loose, and while the farmer's wife was herding her cattle together, Uude had tasted the meat on the frying pan and printed cat's paw prints at the "scene of the crime". The earliest recording of this event in the archives dates back to 1899, and the most recent is from the year 1972.

Uude was not used to washing himself, he is known to have been "extremely dirty"; his response to similar indications was that horses never washed their eyes. People of Väljataguse village characterised him as having "long hair, [looked] like a scarecrow", and in Kehala village, unkempt girls were scolded: "[You look] just like Uude of Hulja!" Only on rare occasions had he agreed to go to the sauna, and he himself said that he got rid of lice by throwing his shirt into an ant's nest. In his older years he had real problems 
with vermin, and several families refused him shelter for that reason. The people of Kunda remembered how Uude had sunk himself under the water with all his clothes on, stood there for a while, and after that walked around until his clothes were dry again.

Uude's greatest peculiarity was his choice of clothes, which were rather unusual. The accounts mention all sorts of things about his clothing: wearing several overcoats on top of each other, the undercoat longer than the overgarments, a skirt on top of slacks, a long velvet dress, a long white shirt, seven coats on top of each other, a long women's coat, a colourful overcoat, colourful pants, red pants, a red smock, a skirt composed of two large scarves, a patchwork quilt wrapped around him, a fur coat inside out, squirrel skins hanging all over him, wearing a fur hat in summer, a German soldier's helmet, lady's hat, even fatigues. The accounts suggest that Uude preferred wearing longer clothes. Once, the mother of a man from Kõrgemäe village had asked Uude why he had been wearing a short dress ending above the knee, and the answer was: "You stupid woman, who wears a long dress when there is morning dew?" In Pajusti village he was remembered to have worn hare furs, leaving the hands-legs uncovered. Uude has said he preferred dresses and skirts because they felt comfortable. In Kadrina he was remembered to have worn dresses in his older years. People in Uduküla village thought he dressed at random, depending on whether he was given a skirt or pants. According to a characterisation recorded at Kohala village, he sometimes wore all the clothes he was given on top of each other. The garments he did not need he left behind, so his overall appearance was not too ragged. People from Tirbiku village have said that sometimes the parish administration had even bought new clothes for him, including underwear. He was often seen wearing a fur coat in summertime, which he commented as follows: "I don't always want to sleep inside, then it is good to sleep in a fur coat. Me and the sheep, we wear it the right way, whereas other people wear it inside out" (Avido v.); "But sheep wear their coats all through the summer" (Pihuvere v.); "If it protects from cold in winter, it should also protect from heat in summer" (Kloodi v.).

The folk tales do not, however, include any reference to transvestism as the reason for Uude's wearing women's clothes. We might nevertheless assume it, although the tales do not elaborate on the 
subject "Uude and women". In Läsna village people have said that Uude preferred households with young maidens, saying that it was an opportunity to make acquaintances. In another village, people said the same: Uude had said that "his heart desired and his eyes saw, but who would give 'it' to a poor beggar", suggesting that he would have wished to touch a woman had he not been driven away (Põdruse v.). An alleged saying by Uude has been recorded in Salla village: "Women have a power of electricity, you are drawn to them." Just as many accounts mention his 'cold shoulder'. Wondering at the radio as a novelty in the village, Uude had said that it was nice to look at it, but he was bored by the women who came there to listen to sermons. In Levala village a female informant had recalled: “"Why haven't you married?" I asked. - "Why should I marry, the kids start breeding then."' He also gave a rather categorical reply to a similar question: "I won't ever go and ask for a woman's hand. Cradle and bed are just a pain in the neck" (Lahe coastal v.). If Uude had been particularly interested in women, or had not tolerated them at all, it would be reflected in the folk tales. In Uduküla village people said: "He never talked of marriage." Apparently, it was Uude's preference towards women's clothes that lead the villagers to argue about his possible hermaphrodism: once, when he spent a night in a household, someone called Mari had promised to take Uude to the sauna and make sure whether he was a "halfman" or not (Jõepere v.).

There were other inferences to his poor clothing in the accounts of village people. In the autumn, when it was already cold, Uude was seen trampling barefoot in the mud, his trouser legs tucked up. Uude had caught cold and come down with cystitis (Rakvere town). In Levala village, he was remembered to have walked barefoot on ice, without gloves, and wearing worn boots around Christmas time. When asked why he was walking barefoot at the time of the potato harvest late in the autumn, he had replied: "Dogs always walk barefoot," and when he was told that dogs were born to walk barefoot, he had answered with a question: "Were you born with socks and boots on?" (Laheküla v.). Uude also admitted there were plenty of families who "would know that I have nobody to knit my socks" (Avido v.). And what was often considered a peculiarity was just a makeshift garment. Uude "remodelled" his clothes, cut the legs off socks and boots and tied them to his soles and wrapped rags around 
his freezing feet. A recollection from Karunga village ran: "I remember him wearing a colourful overcoat with long wide sleeves. He had sewn it himself from patches. The coat was made of long patches of cloth. When we asked Uude: "Why do you wear a colourful coat like that?" the answer was that it was the coat of the Wise Men from the East, and that he would wear the coat of the wise, too. The shopkeeper who had cut Uude this strip of cloth could not get rid of the rest of the roll, as no woman would buy this cloth after having seen it in Uude's colourful coat. Some people sewed Uude clothes, and he also sewed or fitted them himself, but he was mostly given ready-made clothes. He made straw mats, and wrapped them around himself, explaining that the straw coat protected him against the stones thrown at him by village boys, the horns and feathers served as protection against savages and the feathers kept him warm (Kõldu v.). Some stories, however, told how village boys set his straw cabin on fire.

Discussing Uude's clothing habits, we should mention other reasons for his peculiarity. Once he had stuck burdock burs all over his clothes, saying: "Otherwise people wouldn't stare at me" (Karunga v.). In the Põlula estate Uude had walked around, a scarf over his head, saying that he "sees too much of this world" (Inju v.). An informant born in 1896 remembered that he must have been 8 years old when this event took place, so the "man of the world" must have been 42 at that time. He must have looked quite impressive wearing straws, robes or impersonating the devil. Folk tradition introduces a number of different versions of his clothing, also offering various reasons why Uude did so: whether he liked it, was trying to attract attention, beg for money, or scare people?

His interest in wearing disguises could be traced back to his boyhood, when he had to work in the fields of the estate. The ryereapers had been distracted from their work and kept staring at the boy: the latter had run around neighing like a horse, had tied a rye sheaf to his back and attached stalks for mane and tail. $\mathrm{He}$ must have liked being in the centre of everyone's attention. He impersonated horses later as well. In Rägavere village, people said that he had arranged the straws to look like a horse and kicked when seeing another horse on the road. The landlord of TõdvaKõnnu had driven the "horse" who sprinkled water from a bottle from under his straws, out of his house (Kloodi v.). His habit of 
walking on horseshoes tied to his boots is described in quite different versions: one shoe pointing the other way, so that no-one would understand where the "horse" had gone; Uude had taken off the horseshoes so that people would think the devil had disappeared; Uude had teased the signalman by making horse's hoof-prints on the railroad between Tapa and Rakvere; Uude had trampled around the Mädapea estate's park on horseshoes, so that the gardener would think it was the horse who did it, etc. He himself commented as follows: "I entertain people, sometimes," but also mentioned a more practical reason: "Then no-one would know where I come from and where I go" (Haljala p.). There are different stories about how he got the cattle hides for his devil costume (e.g. that the front of Uude's costume was of brown heifer, cow or calf hide, and the rear side was made from a piebald animal). His horns were also described in various ways (made of twisted straw, cut from a bootleg, buckhorns, cow horns with hide, etc.). Uude was spotted in his devil attire in different places, such as, for example, in the woods, on the forest path, in the town of Rakvere, on a village path, on Lehtse railroad, near the cemetery in Kadrina, etc. According to an account from Kõldu village, a startled village officer had told the hairy monster: "If you're a devil, then back off, if you're a Christian step forward," but Uude had not said a word. When a policeman in Kunda had pointed a gun at him, Uude had replied: "I'm a man just like you" (Tirbiku v.). In Kadrina, he told an officer not to shoot, as the bullet would not stop the devil. We might now assume that Uude impersonated the devil a number of times, and kept on doing it, but the stories always end with Uude getting shot. The shooter is either the village officer, constable or policeman of Kunda or Kadrina, the baron of Aaspere or Hulja, or someone else he encountered on his travels, and in these stories Uude is always hit, either in the leg or in another spot. Uude's appearances in a pastoral robe or a coat resembling one were also spotted in different places. According to an account a shopkeeper of Haljala was quarrelling with the church minister, and had given Uude the robe cloth to ridicule him (Hulja v.). Uude had appeared at the Sunday cemetery service in Haljala dressed as a church minister. Another account told that Uude had come to Haljala to assist the minister with a funeral ceremony (Aasu v.), and according to yet another account, village boys had bought Uude some vodka and told him to give his blessing to the people (Jõepere v.). The minister of Kadrina 
had told his "rival" to remove the white clerical collar (marking the ordained vicars), and made no more fuss over it. An example of the self-appointed minister's "Sermon on the Mount" would be as follows: "Blessed are the farm hands of the Moora estate, who bow to their landlord. Blessed are the girls who have many admirers, as they shall end up spinsters anyway" (Salla v.).

The custom of frightening children with beggars who stayed at households was very common in village communities at the first part of the 20th century. Several accounts suggest that Uude was used to frighten children as well. No wonder the children were terrified of him, or that Uude was thought to have worn his peculiar clothes to frighten people intentionally, especially considering that he did not socialise with the whole community, thus contributing to the formation of his rather bad reputation. And, as if to revise such opinions, the narratives contain an even larger number of accounts saying that Uude got along with children rather well: he used to carve them wooden toys, made them willow whistles, tell them jokes, sing and read to them, entertain them by imitating bird songs and go from house to house with them at Martinmas. An old man from Põdruse village recalled how he had broken a bowl in his childhood. Uude had glued the pieces together and placed the bowl at the very edge of the table, saying that then it would break in someone else's hands. Certainly, not all children were nice to Uude, so he probably had to scare them sometimes.

What should we make of the report saying that Uude had performed in a play Koit ja Hämarik ["Dusk and Dawn"] in his youth (Aruküla v.), or that he was asked to go on the stage? (Avido v.) He might have been asked to play because of his ability to imitate bird songs. According to an account recorded at Kloodi village he had memorised the play Koit ja Hämarik word by word and knew it by heart. In any case he enjoyed his act on the big stage of life. An old man (born in 1892) remembered that once when he was a young boy, Uude had been staying at their house; young people had been playing music and dancing, but Uude had refused to dance, and had entertained others by imitating the song of the nightingale and playing on a wooden self-made pipe instead. His masterful imitation of bird songs, especially that of the nightingale, has been mentioned in several accounts. Uude also performed at the estates where he was rewarded with food and money. At a Midsummer's fair in 
Rakvere he had wished to go to the circus, but had no money for the ticket. Thus Uude had sung in his beautiful and strong voice, and also danced a folk dance on crossed sticks together with some other men. And as there were plenty of vacant seats at the circus, he was asked inside and the curious audience came along. Perhaps he might have found a permanent source of living there, had he not been overcome with his fear for work. "I don't need work or a salary, and I don't intend to earn money for you either," he said (Mädapea v.). Once, coming from Nagala, Uude intended to spend the night at the "Kruusimäe Inn" in Kadrina, and seeing a precentor approaching he howled at him like a wolf. The frightened precentor ran to the inn and treated everyone to vodka to come and drive away the wolf. At that moment Uude had entered and said: "The wind may blow and the wolf may howl, and nobody can keep them doing that" (Jõepere v.). Uude has also impersonated an ox for money: once he was seen scraping on the manure piled together by a street cleaner (Pajusti v.). Seppo Knuuttila has argued that a similar pattern of behaviour (impersonating a horse or ox to an audience) serves as an example of the relativity of the notion of humour: the imitation of a scraping ox or a galloping horse could have seemed humorous only within the framework of the contemporary social surroundings, and performed only by a certain person - a ritual clown, or a village fool playing the role of a jester (Knuuttila 1990: 40-41). The folk tales reveal that Uude could carry off an equally masterful imitation of any person or animal (the tales mention horse, ox, wolf, bear, nightingale, cuckoo, skylark, vicar, devil, etc.). Uude has been called a trickster, a pretender, a simulator, indolent, a fraud, and all this seems to be justified. Hence he dyed his feet red with cranberries (or currants), spread mashed potatoes all over his face or wrapped swine's bladders around his legs to appear more sick in case he met gentlemen on his way. $\mathrm{He}$ himself has said that he could walk to the Vinni estate in a normal manner, as it lay in the woods, whereas the Inju estate was in the open, and it would be more profitable if he pretended limping long before he reached the house (Pajusti v.).

Uude used his sonorous voice to sing by request as well as on his own initiative. On a 'cemetery Sunday' in Järva-Jaani he was singing a song Priius, kallis anne ["Freedom, the Sweet Gift..."] at the churchyard gate, when another beggar called Kargu-Jaan [Crutch- 
John] became jealous and hit him with the crutch. Uude had broken his crutch and promised: "I'll never go near Jaan again, otherwise we'll quarrel again” (Lasila v.). In Põdruse village, however, the fight was known to have taken place in the beggar's chamber of the Väike-Maarja church. Generally, Uude was known to have been a peaceful person who never raised his hand at anyone, never got into trouble, did not lie, pocket, cheat or steal. It was said that if he did not happen to like something or someone, he compiled a satirical poem about it or him. Uude knew a great number of songs, and the lyrics or tunes of several folk songs and several published songs were considered his creation. The archival material does not reveal whether Uude really did compose songs, or if he sang songs he had heard from others. The song called Kuidas Krapi Kai taeva sai ["How the Tittle-Tattler Went to Heaven"], which was popular all over the country and was most likely spread in print, was considered Uude's creation: the Tittle-Tattler would have been his grandmother. Uude had confirmed this himself (Rakvere town), and was known to have composed a song about every village. Uude's interest in reading was also remembered. People have seen him reading newspaper extras; he knew the Bible well and could explain it; read the newspaper fluently; kept almanacs under his hat, from which he took the jokes he used to read to children. Someone from Põdruse village recalled having lent Uude a book to read, and afterwards Uude knew all the stories in the book by heart. Uude had also studied ecclesiastical texts, and knew the Bible, using biblical quotations in his answers; his eyesight was good even in his older years. The accounts also mention his attending a prayer circle, his selling religious brochures for 15 cents a piece, and that he was seen taking Communion at Kadrina Church (the church minister had administered the Eucharist to him before the others). His use of speech was regarded as follows: he expressed himself well; was always loquacious; had a ready tongue; was full of words; was a wandering homeless village 'philosopher'. Uude has said: "If I ever take a disciple, he must be good at bantering" (Avido v.).

The consideration of the cultural context of the period is compulsory in the analysis of the Uude cycle (cf. Kaivola-Bregenhøj 1992: 162-163). As Uude was a remarkable exception among all the other dependants of the community, who were mostly bereft of reason, the accounts of his peculiarities were larded with remarks, such as: he had a friendly mien; he was a handsome man; was a poor 
soul; was not ignorant; told practical jokes; was a man of his word; was an honest man, etc. The tales collected in the second half of the century seem to contain more evaluative comments also because the attitude of Uude's contemporaries had changed over the decades. The episodes based on Uude's witty remarks are mostly presented in random order as a thematic cycle, which is made tangible by adding real place names, and completed with a shorter or longer characterisation. A few stories, however, introduce a longer course of events. I would hereby like to present one of them in full. There is nothing unusual in applying verse form to local narratives, and the use of liturgical texts in the narratives is also quite common elsewhere in Estonia (Hiiemäe 1978: 78-79).

In the Confirmation Room.

Once the confirmands of Kadrina congregation invited Uude to their classroom. This was strictly forbidden. They offered him tobacco and vodka, and asked him to sing something cheerful. And Uude sang:

There are many girls around us,

Tra-la-la and til-til-ta,

Wishing men would think of them as

Tra-la-la and til-til-ta,

Beautiful and noble ladies,

Whom they'd like to marry, maybe.

Tra-la-la and til-til-ta,

Whom they'd like to marry, maybe.

Before church they can get no rest

Tra-la-la and til-til-ta

And have to dress in Sunday's best

Tra-la-la and til-til-ta

To show off and to have some poise

And steal a secret look at boys

Tra-la-la and til-til-ta

And steal a secret look at boys.

There is mould in their beer kegs

Tra-la-la and til-til-ta

And bedbugs in the posts of their beds

Tra-la-la and til-til-ta

Front doors blocked with junk and scrap 
Piling up and like a trap

Tra-la-la and til-til-ta

Piling up and like a trap.

All of a sudden, minister Treuer enters the room and asks: "Who is singing here?" Seeing Uude among the confirmands he says: "This isn't the place for singing dirty songs, we sing clerical songs here. Have you been to church and can you sing clerical songs?"

Uude sang in response:

My Shepherd, sure you can

Give mercy to your lamb.

Hold me in your arms

And guide me on my path.

Don't you want, indeed,

To help me in my need?

"Very well," the minister interrupted. "Why haven't you been to confirmation classes?"

"I have nothing to learn there," Uude answered.

"Really! Are you familiar with the Ten Commandments?"

"Clear as crystal!" Uude replied.

"Tell me the first Commandment!" demanded the minister.

Uude named it effortlessly. Then the minister asked the sixth, the fifth, the eighth Commandment, until all the ten were named.

The minister turned to the confirmands saying: "Do you see, boys? This is how you should all know the Ten Commandments."

"Can you read the Lord's Prayer too?" the minister asked Uude.

"I can even read it backwards," Uude answered and began to read: "Amen, eternity into glory and might and Kingdom is thine for evil from us deliver..."

"Quiet!" yelled the minister. "What a foolish profanation of the prayer! Who taught you this?"

"Need was my teacher. If the devil comes haunting me I have no use for the Lord's Prayer, so I read it backwards and the devil backs away from me with horns and tail and all."

"Then have you seen the devil with horns and tail and all?" the minister asked.

"I have even finger-wrestled with him," was Uude's response. The confirmands burst into laughter. 
"Quiet!" yelled the minister again. "What a silly thing to laugh at! Go home and stop disturbing the boys," he said angrily.

"I have no home."

"Where are you from and where were you going?" the minister inquired.

"My home is where the wind blows and that is where I'm going," Uude replied.

"Yes, I can see you're not utterly stupid. But why don't you work and have a family?" the minister asked then.

"I'm not utterly stupid, as you said."

"Listen, Uudeberg, come to the study of the vicarage some day. I would like to talk to you," the minister's voice softened.

Uude and the minister left the room. RKM II 283, 125/9 (2)< Kadrina parish, Jõepere village - L. Palu < Villem Vunderlich, born in 1895 (1971)

As we can see, Uude had no respect for people of higher social rank. Once he had cast a sack of bread given him by the landlady of Vihula into the river: "Do they think I am the beggar of Vihula estate or what?" (Avido v.). He had composed a song about the landlord of the Saksi estate, how he had bitten the landlord and a doctor was sent for him (the song could have been composed by Uude, in fact). Bevern had liked the song and rewarded Uude for that (Rakvere t.). The baron of Palmse, who was a skinny man, had offered Uude work making hay, but the latter had declined the offer, saying: "Then my neck will be as scrawny as yours" (Avido v.). When the estate lands were distributed in lots, Uude said: "Now my life will get worse, too, as there is no place left to go: the count of Udriku will be snooping around in Tokulopi village and the baron of Undla will be making the rounds in Sootaguse village. Soon I will have no place left to go" (Põdruse v.).

There is a well-known joke in the Estonian folk tradition, in which a minister of some congregation has a habit of not returning change to peasants who pay with a larger bank note, and saying "No change returned." Taking the Communion the peasant drinks up the wine cup and says the same words. This incident has been attributed to Uude, who is known to have said either: "No change returned", or "This will be sufficient for the rest of my life". The role of the greedy minister has been attributed to the minister of Haljala, Uude's neighbouring parish, as well as to the minister of Kadrina, Uude's 
home parish. In response to the complaints of the furious priest, who suggested the Undla parish administration get rid of all of the insane, Uude started to pull off crazy tricks. Uude was acquitted by the parish court, so he had enough reasons to pretend to be out of his mind, although people said that he was not very sane later on. (Rägavere v.). Those incidents about Uude as told in folk tales inspired the parish elder of Kadrina to thumb through the old church registers even tens of years after Uude's death. According to him, the last record concerning Uude in the register reports of his taking the Communion in 1900 (Uude was then 38 years of age).

According to the recollections of conscripts, Uude had appeared at the local recruiting office in strange clothes, had participated in the drill, shared food with the conscripts, told them jokes and let them treat him to vodka and tobacco. With the breakout of WW 1 he had gone to be admitted to active service (Vatku v.). The military administration told him to wait for a while, then he would be called to the service (Väljataguse v.). But Uude had said: "I'm too old, they wouldn't take me." When the passers-by had wondered about it, arguing that even the most stupid people are admitted to the National Defence League (a voluntary politico-military organisation active during the period 1918 - 1940), Uude had commented: "Well, yes, there you have it" (Koeravere v.). These army stories might lead one to believe that they served Uude's purpose to openly display his ineligibility. Once accepted as fit for service, he snuck out of the barracks at night. According to an account recorded in Salla village, Uude would have had nothing against working in his old age, but his life was over. He himself said: "I could have led an ordinary life, too, but I was afraid of the service." When he was taken to be "examined in Tartu", he turned out to "be a philosopher, and not a fool. He wasn't weak-minded."

His masterful skill in using synonymy helped to establish his reputation as a philosopher. On the suggestion to put some medicine ['rohi' in Estonian] on his aching feet, he replied: 'I walk knee-deep in grass [also 'rohi' in Estonian] every day of my life" (Aaspere v.). To the question "Do you have a passport ['pass' in Estonian], that you can travel like this?" he had answered "Sure I will sing bass, if you will sing the treble part" (Kabala v.). 


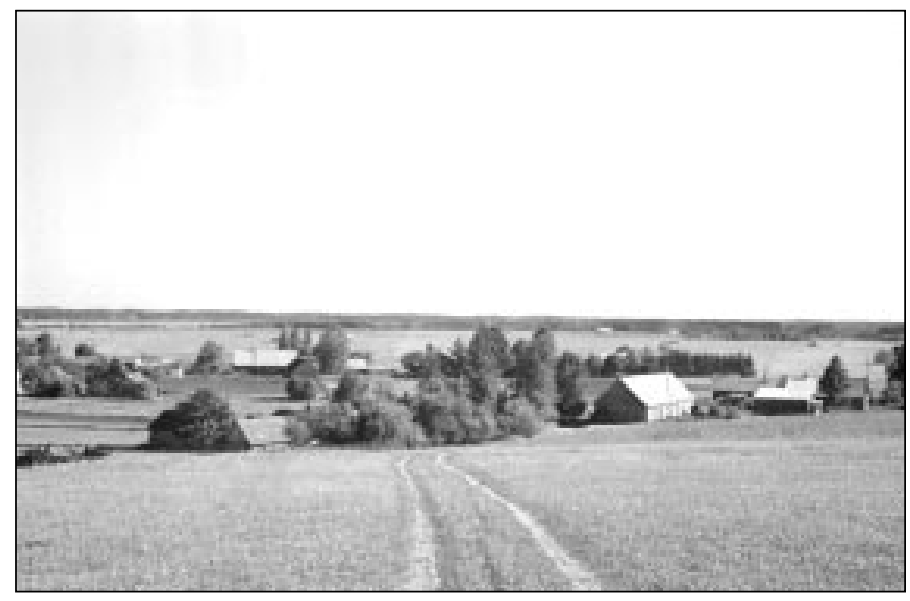

Where Uude used to travel - a road to Sootaguse village. Photo by L. Briedis 1969. Photo collections of the Estonian Folklore Archive.

Travelling alone Uude had to experience both good and bad in his long life, and during his solitary walks he had come to think about his status and his relation to other people. Apparently he did care what people thought of him. "People never call me by my real name. I am Gustav Uudeberg, but they call me Uude of Hulja," he wondered (Avido v.). He is known to have said a similar thing in Ojaveski village, his family name being known as "Uudelepp" there. Once, on the road near the "Tõrremäe Inn" between Rakvere and Haljala, Uude had heard someone say to pick up the 'beggar on crutches', upon which he had run away (Veltsi v.). Another account of his refusal recounted that he had said: "I'm not so badly off that I should be carried by animals" (Avido v.). People also knew that his hands had frozen once, so that he could no longer eat with a spoon, as they were shaking so badly. When advised to seek treatment, he had said: "I know more than any doctor" (Avido v.).

Hulja Uude tried to outlive his fate. Imitating the song of the nightingale in the park of Udriku estate, he had told the count who had stopped to listen: "I'm the king of nature. The king does not take alms, and the nightingale does not sing for money" (Uduküla v.). Comparing society and nature, he tended to prefer nature: "I like to be with the birds in the woods and nature, but I don't like living among people" (Levala v.). When asked where he was registered, 
Uude's answer was always the same: "Nowhere. I'm registered where the birds are." (The parallel with birds determines the status of an outcast who does not subject to anyone.) The homeless traveller thought that forests "were good for three things: they provide shelter against the wind and against snowstorms and protection against pickpockets" (Ohepalu v.). Uude even wished to die in the woods. He had said that "he would rather not be buried under the sand, as it is so heavy. He would rather go to the woods and die there" (Haljala p.).

Uude lived to be an old man, perhaps because he spent so much time outdoors, because of his travelling life and careless mind; he himself promised to live to at least a hundred years of age. If people wondered "You're still alive?" he replied: "And I don't intend to die, people need me to entertain them" (Rägavere v.). The aged village philosopher avoided social welfare and ran away from different rest homes for the aged (the accounts mention the Udriku, Aovere estate and Aa rest homes). According to one account he had been afraid that after his death he would be sent to the anatomical theatre of the University of Tartu, to be pulled and poked at (Kadrina p.). Information about his death has undergone transformation, as has the whole oral heritage. Death in a nursing home would have sounded a little too conventional for his personality; people said he had been found in the woods. A hearsay which circulated in Haljala during World War 2 said that Uude had been found dead on a path in the woods: probably taken for a spy and killed. According to an explanation that spread around Rakvere, he had been hit by a train and was found dead in the woods. Or perhaps there is some truth in a third explanation, according to which he had collapsed on a forest path in Pala village in 1941, where he was found and taken to the Aa nursing home, where he died after a few days (Avido v.). Further inquires from the nursing home resulted in the response that they had no detailed records about the patients from that period, but the deceased who had no relatives might have been buried in the local cemetery.

To sum up we should note that Uude of Hulja as a personality bears some resemblance to Petter Abram Heräjärvi (1830-1885), a Finnish village character, aka the priest of Kalkkimaa, who also became a matter of discussion regarding whether he was a madman or highly intelligent. Matti Kuusi argued that he was a unique combination of 
amateur artist, trickster and buffoon (Kuusi 1990: 89-93). In comparing the stories of these two men, several common features emerge: both were tall, wore women's clothes, refused to work, feared becoming the study material of city doctors, used to sit on the floor (denoting, perhaps, their belonging to a lower social rank), liked to be around children and entertain them, had a good knowledge of the Bible, were known as song-makers and made witty remarks.

Even though Uude's attempt to avoid any possible criminal incidents (his attitude towards money, never having matches, etc.) was considered to be one of his peculiarities, and disregarding all the features that were condemned in the contemporary village communities, he proved to have several valuable qualities, such as the lack of respect towards those of higher social position (barons, church ministers, etc.), his imitating skills, and his wittiness. Uude was a remarkable yet contradictory figure, and in that could be compared with Juho Mäkäröinen (1892-1967, aka Heika Jussi), a Finnish character described by Tuija Joutsivuo (1995). When Uude was alive, people also discussed his categorising families and whole villages into those worth socialising with and those to be ignored. The people whom he found worth socialising with were eager to spread his words, complementing the oral biography of the popular character with accounts of incidents experienced by themselves or their relatives.

I have tried to observe both the narration of the Uude cycle by provoking it as an outsider to the village community, and also the spontaneous discussion and elaboration of the subject as a part of the group (among my husband's relatives). And as usual, in the stories about local heroes, it depends on the narrative situation, the competence of the listeners, their interference with the course of the narration, or other circumstances. An incompetent listener will be offered more information, and is sometimes even told all there is to know about a topic. At the same time, the spontaneous narration also tends to form a type of conglomeratic cluster. A similar amorphous nature of the structure has also been noted by Kristi Salve (1999: 248) in her work on Kordo, a character in folk tales who was considered a witch and a prophet. Single episodes of the narrative might be considered comical stories for their stable form and humorous purpose, but the narrative as a whole does not usually belong there. Thus a folklore researcher once again has an 
opportunity to witness the contingency in genre classification of such narratives and a chance to observe how folklore is formed and what is it formed of. At least as far as the Uude-cycle is concerned, this seems to be the most meaningful thing to do.

Translated by Kait Realo

\section{References}

Hiiemäe, Mall 1978. Kodavere pajatused. Kujunemine ja koht rahvajututraditsioonis. Tallinn.

Hiiemäe, Mall \& Krikmann, Arvo 1992. On stability and variation on type and genre level. Folklore processed. Ed. by Reimund Kvideland in coop. Studia Fennica. Folkloristica I. Helsinki, 127-140.

Joutsivuo, Tuija 1995. The social status of a local fool in a finnish village. Folk belief today. Ed. by Mare Kõiva and Kai Vassiljeva. Tartu, 164-167.

Kaivola-Bregenhøj, Annikki 1992. The contents of narrative. Folklore processed. Ed. by Reimund Kvideland in coop. Studia Fennica. Folkloristica I. Helsinki, 153-166.

Klapp, Orrin E. 1980. The fool as a social type. The pleasures of sociology. Ed. by Lewis A. Coser. New York.

Knuuttila, Seppo 1990. Yhdeksääkymmentäyhdeksää lajia. Hullun kirjoissa. Näkökulmia suomalaiseen kylähulluuteen. Ed. by Pekka Laaksonen, Ulla Piela, Pirkko Lahti. Helsinki, 39-48.

Kuusi, Matti 1990. Kolme juròdivyitä. Hullun kirjoissa. Näkökulmia suomalaiseen kylähulluuteen. Ed. by Pekka Laaksonen, Ulla Piela, Pirkko Lahti. Helsinki, 88-97.

Masing, Uku 1993. Prohvet Maltsvet. Vaatlusi maailmale teoloogi seisukohalt. Tartu, 111-157.

Salve, Kristi 1999. Kordo - a sorcerer and/or prophet. Studies in folklore and popular religion. Vol. 3. Ed. by Ülo Valk. Tartu, 245-267.

Sihvo, Hannes 1990. Hullu kirjoissa.Hullun kirjoissa. Näkökulmia suomalaiseen kylähulluuteen. Ed. by Pekka Laaksonen, Ulla Piela, Pirkko Lahti. Helsinki, 13-38. 